\title{
Pengaruh Kepengawasan dan Kepemimpinan Distributif-Relasional Terhadap Komitmen Organisasi Kepala Sekolah Dasar di Kabupaten Semarang
}

\author{
Sophia Tri Satyawati \\ sophia.trisatyawati@uksw.edu \\ Magister Manajemen Pendidikan FKIP Universitas Kristen Satya Wacana \\ The Influence of Supervision and Relational-Distributive Leadership Towards Organizational \\ Commitment of The Elementary School Principals in Semarang District
}

\begin{abstract}
The purpose of this study is to uncover the influence of supervision and distributiverelational leadership on the organizational commitment of principals. The method used in this study uses quantitative methods. The population in this study was the principal of Elementary School in Semarang District numbering 510. The sample in this study was determined based on a cluster sampling technique of 127 people. Data collected through a questionnaire that has been tested for validity and reliability. The data analysis technique uses path analysis with SPSS 21 software. The results of the study show that: (1) positive and significant supervision directly influences the principal's organizational commitment; (2) distributive-relational leadership positively and significantly directly influences the organizational commitment of the principal; and (3) supervision positively and significantly influences indirectly through distributiverelational leadership to the commitment of the principal's organization.
\end{abstract}

Keywords: Supervision, Distributive-Relational Leadership, Organizational Commitment

Received date: 8 Januari 2020

Revised date: 11 April 2020

Accepted date: 12 Mei 2020

\section{PENDAHULUAN}

Setiap pemimpin dalam suatu perusahaan atau organisasi harus mempunyai komitmen dalam bekerja. Apabila suatu pemimpin perusahaan atau organisasi tidak mempunyai komitmen dalam bekerja, maka tujuan dari perusahaan atau organisasi tersebut tidak akan tercapai. Pemimpin yang memiliki suatu komitmen, akan bekerja secara optimal sehingga dapat mencurahkan perhatian, pikiran, tenaga dan waktunya untuk pekerjaannya, sehingga apa yang sudah dikerjakannya sesuai dengan yang diharapkan oleh perusahaan atau organisasi. Komitmen organisasional pemimpin merupakan faktor penting yang meneguhkan pemimpin dan orang yang dipimpin dalam suatu organisasi menjalani tanggung jawab kepemimpinan yang diembannya(Sergiovanny, 1987).

Demikian juga di sekolah, komitmen organisasi kepala sekolah sangat penting karena proses untuk memobilisasi komitmen harus dimulai pada tingkat tertinggi organisasi. Ketidakkonsistenan dan tidak adanya rasa percaya terhadap pemimpin akan mengurangi kejelasan visi dan misi dari suatu organisasi. Sekolah membutuhkan pemimpin yang efektif, yang mempunyai komitmen, dan yang mempunyai kemampuan mempengaruhi perilaku anggotanya atau anakbuahnya.

Pembentukan dan peningkatan komitmen organisasi kepala sekolah dipengaruhi oleh beberapa faktor. Steers dan Porter dalam Sopiah (2008:64) mengemukakan bahwa pengawasan termasuk salah satu faktor organisasi yang mempengaruhi komitmen yang dapat membentuk atau memunculkan tanggung jawab. Hasil penelitian Pratiwi (2007), menunjukkan bahwa komitmen organisasional dipengaruhi oleh pengawasan.. Demikian juga dengan hasil penelitian Febriani (2017) menunjukkan bahwa pengawasan berpengaruh positif dan signifikan terhadap komitmen organisasi. Penelitian Ratiningrum (2017) menunjukkan terdapat pengaruh yang signifikan secara parsial peran pengawas sekolah terhadap komitmen kepala sekolah SD di Kecamatan Seputih Banyak Kabupaten Lampung Tengah.

Setiap pelaksanaan tugas pokok dan fungsinya kepala sekolah perlu mendapatkan kepengawasan oleh pemangku kepentingan untuk mengetahui keterlaksanaannya. Pihak yang 
berwenang untuk melakukan kepengawasan terhadap kepala sekolah adalah pengawas sekolah. Pengawas sekolah memiliki posisi sangat penting dan berpengaruh terhadap pencapaian tujuan, visi misi, dan kemajuan sekolah. Tugas pokok pengawas sekolah dalam menjalankan fungsinya sebagai pengawas manajerial sangat strategis bagi kepala sekolah untuk meningkatkan komitmen organisasi dalam rangka meningkatkan kinerjanya agar mutu sekolah dapat meningkat (Direktorat Tenaga Kependidikan, Kemendiknas, 2013: 20).

Namun fakta di lapangan menunjukkan bahwa peran kepengawasan belum optimal dalam melaksanakan supervisi manajerial. Hal ini bisa disebabkan keterbatasan jumlah pengawas sekolah SD dibandingkan dengan jumlah SD binaan. Jumlah pengawas SD di Kabupaten Semarang tahun 2018 sebanyak 33 orang dengan 510 SD binaan, sehingga seorang pengawas SD bertanggung-jawab pada 15-16 sekolah binaan. Sementara tugas pokok dan fungsi pengawas sekolah bukan hanya supervisi manajerial kepala sekolah tetapi juga meliputi supervisi akademik guru dan kepengawasan terhadap keterlaksanaan delapan standar nasional di sekolah binaan memungkinkan peran pengawas dalam memantau, mensupervisi, mengevaluasi, dan menindak lanjuti hasil pengawasan manajerial berdampak kurang optimal. Hal tersebut berdampak pada komitmen organisasi kepala sekolah di Sekolah Dasar Kabupaten Semarang menunjukkan kurang optimal, seperti: 1) komitmen kepala sekolah untuk mewujudkan visi dan misi sekolah belum tercapai maksimal, 2) masih banyak perencanaan yang dilakukan belum terlaksana maksimal.

Sekolah yang secara rutin mendapat layanan pengawasan oleh pengawas sekolah dengan melaksanakan supervisi manajerial melalui kegiatan pemantauan, pembinaan, penilaian, dan bimbingan teknis menunjukkan komitmen kepala sekolah yang lebih baik daripada sekolah yang kurang mendapatkan layanan pengawasan. Artinya bahwa kepengawasan oleh pengawas sekolah dalam melaksanakan supervisi manajerial berdampak positif terhadap komitmen organisaional kepala sekolah. Hal tersebut karena supervisi manajerial yang dilakukan oleh pengawas sekolah tidak sekedar melakukan penilaian, tetapi juga melakukan bimbingan, pengarahan dan pembinaan teknis sehingga dapat meningkatkan komitmen organisasional kepala sekolah dalam bekerja (Febriani, 2017).

Sergiovanny (1987: 296) menyatakan bahwa kepemimpinan mengarahkan sumber daya manusia membutuhkan tindakan komitmen untuk mencapai tujuan dan sasaran. Kuo, et al (2009: 1168) mengemukakan bahwa pembentukan komitmen organisasi dapat dilakukan melalui kepemimpinan, yaitu kemampuan pimpinan untuk memperhatikan sepenuhnya karyawan dengan pemberi motivasi dan komitmen organisasi melalui pemberian delegasi, tanggung jawab dan memberdayakan karyawan.

Hasil penelitian Hueryren Yeh, \& Dachuan Hong (2012: 55) menunjukkan kepemimpinan positif dan signifikan mempengaruhi komitmen organisasi. Demikian juga hasil penelitian Indayati, Thoyib \& Rofiaty (2012: 353), Omidifar (2013: 266) menunjukkan ada hubungan yang positif dan signifikan antara gaya kepemimpinan terhadap komitmen organisasi. Tetapi berbeda dengan hasil penelitian Hakim \& Hadipapo (2015: 10) menunjukkan bahwa kepemimpinan berpengaruh negatif dan tidak signifikan terhadap komitmen organisasi pada sekolah dasar negeri di Wawotobi. Artinya rendahnya intensitas kepemimpinan maka komitmen organisasi akan semakin turun kepemimpinan tidak berpengaruh positif terhadap komitmen organisasi.

Hasil penelitian Hulpia, Devos, \& Kerr (2009: 312-213) mengungkapkan bahwa jumlah dukungan kepemimpinan memainkan peran kunci positif secara signifikan dalam memprediksi komitmen guru. Pengambilan keputusan partisipatif dan distribusi fungsi kepemimpinan memiliki dampak positif yang signifikan pada komitmen organisasi yang pada akhirnya akan meningkatkan kinerjanya. Dimensi kepemimpinan distributif meliputi dukungan, supervisi dan kerjasama. Peranan pemimpin dalam organisasi kepemimpinan distributif merupakan kepemimpinan yang meliputi pelbagai elemen seperti interaksi, kerja tim, kepercayaan, penurunan kuasa, kolektif dan kolaborasi.

Untuk mengimplementasikan kepemimpinan distributif tersebut dibutuhkan kemampuan relasional kepala sekolah. Kemampuan relasional merupakan keterampilan interpersonal kepala sekolah untuk mengembangkan dan memelihara kualitas hubungan dengan beragam orang di sekolah (Duignan , 2004). Dengan kepemimpinan distributif-relasional, kepala sekolah dapat lebih memberdayakan guru dan karyawan untuk terlibat, sehingga akan memperkuat tim kerja dengan hubungan interpersonal yang berkualitas. Tim kerja yang solid dengan hubungan interpersonal yang berkualitas memudahkan kepala sekolah untuk menciptakan komitmen organisasi.

Melihat adanya kesenjangan antara teori dengan fakta di lapangan dan kajian hasil penelitian terdahulu, serta research gap yang ada terkait dengan isu - isu komitmen organisasi dan faktor-faktor 
yang mempengaruhinya pada uraian latar belakang di atas, rumusan masalah dalam penelitian ini adalah: 1) bagaimana kepengawasan berpengaruh langsung terhadap komitmen organisasi kepala sekolah; 2) bagaimana kepemimpinan distributif-relasional berpengaruh langsung terhadap komitmen organisasi kepala sekolah; dan 3) bagaimana kepengawasan berpengaruh secara tidak langsung melalui kepemimpinan distributif-relasional terhadap komitmen organisasi kepala sekolah. Tujuan penelitian ini adalah mengungkap: 1) pengaruh langsung kepengawasan terhadap komitmen organisasi kepala sekolah; 2) pengaruh langsung kepemimpinan distributif-relasional terhadap komitmen organisasi kepala sekolah; dan 3) pengaruh tidak langsung kepengawasan terhadap komitmen organisasi kepala sekolah melalui kepemimpinan distributif-relasional.

Manfaat teoritis hasil penelitian ini diharapkan dapat menemukan sintesis keilmuan manajemen pendidikan terkait dengan komitmen organisasi kepala sekolah dan faktor-faktor yang mempengaruhinya baik secara langsung maupun tidak langsung, meliputi: kepengawasan dan kepemimpinan distributif-relasional. Manfaat praktis bagi kepala sekolah, hasil penelitian ini diharapkan dapat menjadi sumbangan pemikiran bagi kepala sekolah terutama dalam menjalankan peran dan fungsinya sebagai leader. Bagi Dinas Pendidikan, Kebudayaan, Kepemudaan, dan Olah Raga (Disdikbudpora) Kabupaten Semarang, hasil penelitian ini diharapkan dapat memberikan masukan dalam upaya pengembangan kualitas kepemimpinan kepala dan sebagai pertimbangan dalam membuat keputusan untuk menentukan kebijakan pengelolaan bidang pendidikan dasar.

\section{KAJIAN PUSTAKA}

Pengertian komitmen merujuk pada kesetiaan dan loyalitas. Mowday et al. (1979: 226), mendefinisikan bahwa komitmen organisasi merupakan keterlibatan karyawan dalam loyalitasnya pada organisasi, kesediaan untuk mengarahkan usaha, tujuan dan nilai sejalan dengan organisasi dan keinginan untuk mempertahankan keanggotaannya dalam organisasi. Armstrong (1955: 173) mendifinisikan komitmen sebagai kekuatan relatif dari identifikasi dan keterlibatan individu kepada organisasi tertentu. Kiesler dan Sakumura seperti yang dikutip oleh Salancik (1955: 284) mengartikan komitmen sebagai ikatan antara individu dan tindakan perilaku. Bahkan kata komitmen diartikan sebagai suatu karakteristik intelektual, sifat pribadi seperti kejujuran, yang tidak dapat dimandatkan atau dipaksakan dari luar.

Komitmen organisasional pemimpin (kepala sekolah) merupakan faktor penting yang meneguhkan pemimpin dan orang yang dipimpin dalam suatu organisasi menjalani tanggung jawab kepemimpinan yang diembannya. Robbins dan Judge (2015) mendefinisikan komitmen sebagai suatu keadaan dimana seorang individu memihak organisasi serta tujuan-tujuan dan keinginannya untuk mempertahankan keanggotaannya dalam organisasi. Steers (2002) mendefinisikan komitmen organisasi sebagai rasa identifikasi (kepercayaan terhadap nilai-nilai organisasi), keterlibatan (kesediaan untuk berusaha sebaik mungkin demi kepentingan organisasi) dan loyalitas (keinginan untuk tetap menjadi anggota organisasi yang bersangkutan) yang dinyatakan oleh seorang pegawai terhadap organisasinya.

Mempersoalkan komitmen sama dengan mempersoalkan tanggung jawab, maka rendahnya komitmen mencerminkan kurangnya tanggung jawab seseorang dalam menjalankan tugasnya. Komitmen seorang pimpinan yang dalam hal ini adalah kepala sekolah adalah terkait dengan pendelegasian wewenang (empowerment). Dalam konsep ini pimpinan dihadapkan pada komitmen untuk mempercayakan tugas dan tanggung jawab ke bawahan. Sebaliknya, bawahan perlu memiliki komitmen untuk meningkatkan kompetensi diri. Lebih lanjut Sergiovanny (1987: 276) menyatakan bahwa komitmen diperlukan agar orang-orang dapat bekerja bersama dengan penuh semangat untuk peningkatan mutu sekolah.

Komponen dan Indikator pengukuran komitmen organisasi (Steers, 2002) meliputi: 1) Dimensi identifikasi, dengan indikator: (a) menyukai pekerjaannya di sekolah, (b) mempercayai dan menerima nilai-nilai organisasi dan tujuan organisasi, (c) menyelaraskan perilakukanya terhadap kebutuhan, prioritas dan tujuan organisasi; 2) Dimensi keterlibatan, dengan indikator: (a) peduli terhadap bidang pekerjaannya, (b) kehadiran, (c) mendahulukan misi sekolah daripada kepentingannya sendiri, (d) berupaya yang terbaik untuk sekolah, (e) puas terhadap pekerjaannya; 3) Dimensi Loyalitas, dengan indikator: (a) setia terhadap lembaga sekolah, (b) patuh pada lembaga, (c) bertanggung-jawab terhadap tugas dan kewajibannya, (d) siap berkorban demi kepentingan sekolah. 
Sergiovanni (1987) menyatakan, bahwa pengawasan dalam konteks pendidikan merupakan proses memonitor kegiatan-kegiatan untuk mengetahui program-program lembaga pendidikan yang telah diselesaikan dan tujuan-tujuan yang telah dicapai. Supervisi manajerial atau pengawasan manajerial merupakan fungsi supervisi yang berkenaan dengan aspek pengelolaan sekolah yang terkait langsung dengan peningkatan efisiensi dan efektifitas sekolah yang mencangkup perencanaan, koordinasi, pelaksanaan, penilaian, pengembangan kompetensi sumber daya tenaga pendidik, dan kependidikan (Sudjana dkk, 2011: 21).

Kepengawasan pada lembaga pendidikan/satuan pendidikan menurut Peraturan Pemerintah Nomor 13 Tahun 2015 tentang Standar Nasional Pendidikan, menyatakan bahwa pengawasan/supervisi dilakukan secara teratur dan berkesinambungan oleh pengawas sekolah. Penyusunan program supervisi difokuskan pada pembinaan kepala sekolah dan guru, pemantauan delapan standar nasional pendidikan, dan penilaian kinerja kepala sekolah dan guru.

Komponen dan indikator untuk mengukur kepengawasan (Peraturan Menteri Pendidikan dan Kebudayaan Nomor 143 Tahun 2014) meliputi: 1) Pembinaan, terdiri indikator : (a) Pengelolaan program sekolah berdasarkan 8 SNP, (b) Membantu kepala sekolah melakukan evaluasi diri sekolah (EDS) dan merefleksikan hasil-hasilnya dalam upaya penjaminan mutu pendidikan, (c) Mengembangkan perpustakaan dan laboratorium serta sumber-sumber belajar lainnya, (d) Kemampuan kepala sekolah dalam membimbing pengembangan program bimbingan konseling, (e) Melakukan pendampingan terhadap kepala sekolah dalam pengelolaan dan administrasi sekolah ;2) Pemantauan, terdiri indikator: (a) Keterlaksanaan dan/atau kesesuaian SNP dalam penyelenggaraan pendidikan pada satuan pendidikan, (b) hambatan-hambatan dalam pelaksanaan program, dan (c) data kinerja sekolah dalam pelaksanaan dan pemenuhan SNP; 3) Penilaian, melaksanakan penilaian kinerja kepala sekolah tentang pengelolaan sekolah tahunan dan 4 tahun, 4) Pembimbingan dan Pelatihan, terdiri indikator: (a) Menyusun Program Kerja Sekolah, (b) Pelaksanaan Program Kerja Sekolah , (c) Program Pengawasan dan Evaluasi, (d) Kepemimpinan Sekolah, (d) Sistem Informasi Manajemen, (e) Pembimbingan PTK/PTS, (f) Penyusunan RKAS sesuai dengan SNP, (g) Akreditasi Sekolah

Kepemimpinan merupakan kemampuan untuk mempengaruhi suatu kelompok menuju pencapaian sebuah visi atau tujuan yang ditetapkan (Robbins \& Judge, 2015: 249). Selanjutnya Robbins mengatakan bahwa organisasi memerlukan kepemimpinan dan manajemen yang kuat untuk efektifitas yang optimal. Kepemimpinan sangat dibutuhkan sebagai kontrol kendali sebuah metoda manajemen dalam menjalankan organisasi. Oleh karena itu kepemimpinan sangat berperan dalam peningkatkan kinerja manajerial kepala sekolah sebagaimana pendapat Simamora, Timpe dalam Mangkunegara, 2006: 53; Edmon, 1997, Gibson, 1987 dalam Simanjuntak 2011: 24.

Sergiovanni (1987) menyatakan, bahwa kepemimpinan didefinisikan sebagai keseluruhan proses mempengaruhi, mendorong, mengajak, menggerakkan, dan menuntun orang lain dalam proses kerja agar berfikir, bersikap, dan bertindak sesuai dengan aturan yang berlaku dalam rangka mencapai tujuan yang telah ditetapkan. Elmore (2000) mendefinisikan kepemimpinan distributif sebagai melaksanakan tugas kepemimpinan secara bersama dan saling bertanggung jawab ke arah suatu tujuan bersama untuk meningkatkan kesuksesan sebuah organisasi.

Kepala sekolah sebagai agen perubahan perlu mengimplementasikan kepemimpinan yang sesuai dengan perkembangan dan perubahan. Tren kepemimpinan pendidikan masa kini melibatkan bawahan yang bekerja secara tim, sehingga kepala sekolah tidak boleh secara otoriter bertindak sendiri dalam mencapai kesuksesan organisasi (Rosnarizah, 2009: 11). Tipe/gaya kepemimpinan tersebut oleh Elmore (2000) disebut sebagai kepemimpinan distributif, yaitu melaksanakan tugas kepemimpinan secara bersama dan saling bertanggung jawab ke arah suatu tujuan bersama untuk kesuksesan organisasi. Dalam kepemimpinan distributif, berbagai fungsi kepemimpinan didistribusikan ke beberapa individu yang bertindak sebagai pemimpin. Kepemimpinan distributif melibatkan bawahan dalam pengambilan keputusan. Menurut Ouchi, William (1981), pengambilan keputusan kolektif dan tanggung jawab kelompok memberikan dukungan sosial yang diperlukan bagi tercapainya kinerja puncak.

Untuk mengimplementasikan kepemimpinan distributif tersebut dibutuhkan kemampuan relasional kepala sekolah. Kemampuan relasional merupakan keterampilan interpersonal kepala sekolah untuk mengembangkan dan memelihara kualitas hubungan dengan beragam orang di sekolah (Duignan , 2004). Dengan kepemimpinan distributif-relasional, kepala sekolah dapat lebih memberdayakan guru dan karyawan untuk terlibat, sehingga akan memperkuat tim kerja dengan 
hubungan interpersonal yang berkualitas. Tim kerja yang solid dengan hubungan interpersonal yang berkualitas memudahkan kepala sekolah untuk menciptakan komitmen organisasi.

Menurut Hallinger kepemimpinan distributif diukur dengan 3 (tiga) dimensi (Hallinger, 2003) meliputi: (1) Support, meliputi indikator: menetapkan dan mempromosikan visi sekolah secara kolektif, memotivasi dan merangsang anggota sebuah organisasi; (2) Supervision, meliputi indikator:: mengarahkan, mengendalikan, dan pemantauan; (3) Collaboration, meliputi indikator: pendelegasian tugas keputusan partisipatif keterbukaan anggota tim, dan saling percaya. Jadi kepemimpinan relasional merupakan keterampilan interpersonal kepala sekolah untuk mengembangkan dan memelihara kualitas hubungan dengan beragam orang di sekolah (Duignan, 2004).

Penelitian yang relevan dengan pengaruh kepengawasan terhadap komitmen organisasi telah dilakukan oleh Latif \& Gulzar (2011), Madriaga (2014), Ratriningrum (2017) menjelaskan bahwa kepengawasan berpengaruh terhadap komitmen organisasi.

Penelitian yang relevan dengan pengaruh kepemimpinan distributif relasional terhadap komitmen organisasi telah dilakukan oleh Rabindarang, \& Bin (2014) menjelaskan bahwa kepemimpinan distributif perpengaruh terhadap komitmen organisasi. Hulpia, Devos, \& Kerr (2009) menjelaskan kepemimpinan distributif berpengaruh terhadap komitmen orgnisasi dan berdampak pada peningkatan kinerja. Shalahuddin (2013), Latib, Fathoni, \& Minarsih (2016), Alkahtani (2016), dan Alkahtani (2016) menjelaskan bahwa kepemimpinan berpengaruh terhadap komitmen organisasi. Syafriadi (2015), Hueryren (2012), menjelaskan kepemimpinan berpengaruh terhadap komitmn organisasi dan memediasi terhadap kinerja.

Kerangka konseptual peningkatan komitmen organisasi kepala sekolah dalam penelitian ini divisualisasikan dalam gambar berikut ini:

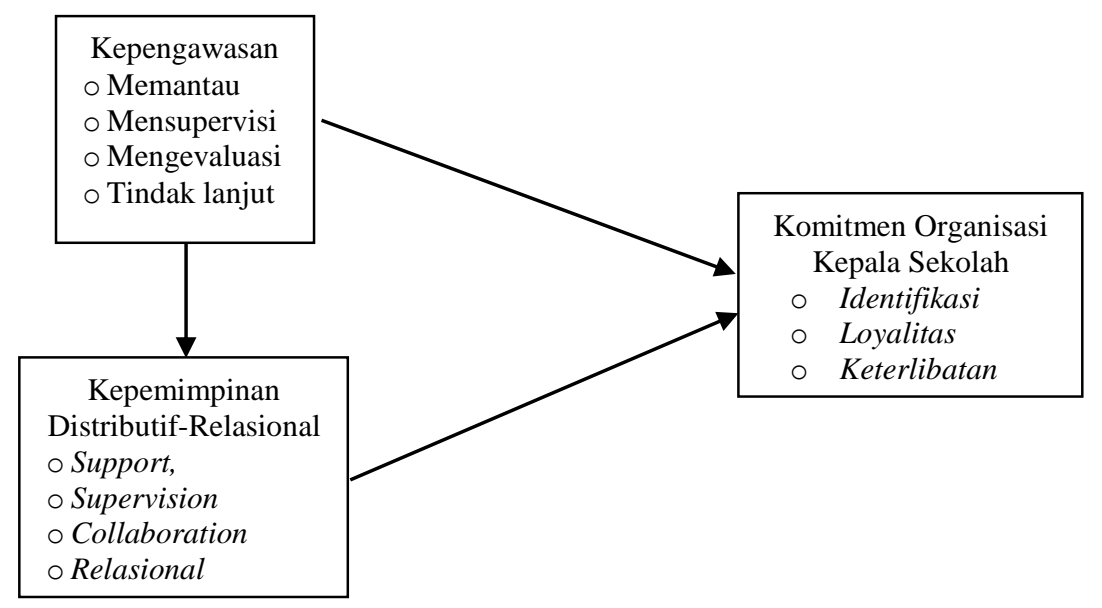

Gambar 1. Kerangka Konseptual Pengaruh Kepengawasan dan Kepemimpinan Distributif-Relasional terhadap Komitmen Organisasi Kepala Sekolah

Berdasarkan latar belakang tersebut, hipotesis penelitian ini adalah sebagai berikut:

H1: Kepengawasan secara positif dan signifikan berpengaruh langsung terhadap komitmen organisasi kepala sekolah

H2: Kepemimpinan distributif-relasional secara positif dan signifikan berpengaruh langsung terhadap komitmen organisasi kepala sekolah

H3: Kepengawasan secara positif dan signifikan berpengaruh secara tidak langsung melalui kepemimpinan distributif-relasional terhadap komitmen organisasi kepala sekolah

\section{METODE PENELITIAN}

Sesuai dengan dengan tujuan penelitian dan sifat masalah yang akan diteliti, penelitian ini merupakan metode penelitian survey dengan pendekatan kuantitatif dan menggunakan rancangan ex post facto bersifat korelasional.

Populasi yang menjadi obyek dalam penelitian ini adalah kepala sekolah pada jenjang Sekolah Dasar di Kabupaten Semarang sebanyak 510 orang. Sampel dalam penelitian ini ditentukan 
berdasarkan tehnik Cluster Sampling (Area Sampling). Peneliti mengambil sampel sebanyak 25\% x $510=127$ orang.

Teknik pengumpulan data pada penelitian ini adalah dengan menggunakan teknik angket dan dokumentasi. Variabel yang akan dianalisis dalam penelitian ini, meliputi: (1) Kepengawasan adalah penilaian responden terhadap pelaksanaan supervisi manajerial yang dilakukan oleh pengawas sekolah terhadap kepala sekolah binaannya dan tercermin pada skor jawaban, meliputi dimensi: pembinaan, pemantauan, penilaian, pembimbingan dan pelatihan. (2) Kepemimpinan Distributif - Relasional adalah penilaian diri responden (kepala sekolah) dalam kerjasama kepemimpinan dengan bawahan untuk membangun kapasitas setiap individu di dalam organisasi bersadarkan pengembangan keterampilan interpersonal dan tercermin dalam skor jawaban, meliputi dimensi: Support, Supervision, Collaboration, dan Relasional. (3) Komitmen Organisasi Kepala Sekolah adalah penilaian diri respoden terhadap perilaku keberpihakannya terhadap organisasi dan tanggung jawab dalam melaksanakan tugasnya yang ditampilkan dalam pekerjaannya sehari-hari dan tercermin dalam skor jawaban, meliputi dimensi: identifikasi, loyalitas, dan keterlibatan.

Setiap item pertanyaan diukur dengan menggunakan tujuh skala pengukuran, dimana 1 menunjukkan "sangat jarang sekali dilakukan" dan 7 menunjukkan "selalu dilakukan".

Untuk menjawab masalah penelitian, dan menguji hipotesis dilakukan dengan cara menganalisis dan menguji model empirik. Pengujian model hipotesis menggunakan analisis jalur (path analysis) dengan software SPSS 21.

Kerangka hubungan kausalitas antar variabel yang diajukan dalam penelitian ini adalah:

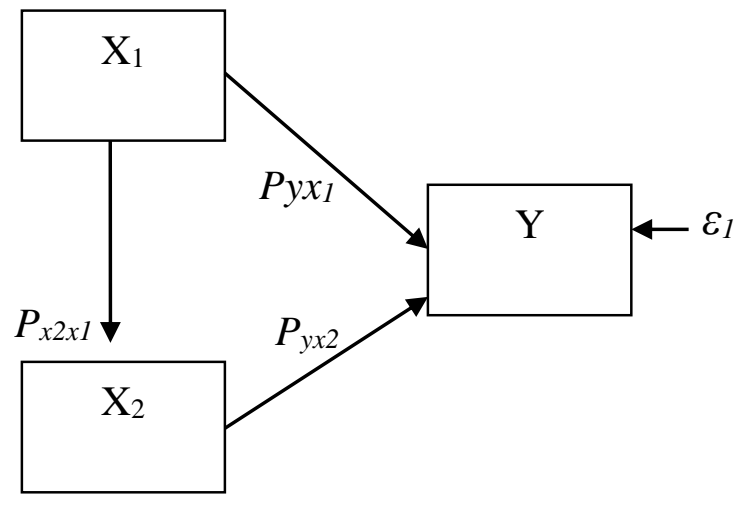

Gambar 2. Hubungan Kausalitas antar Variabel

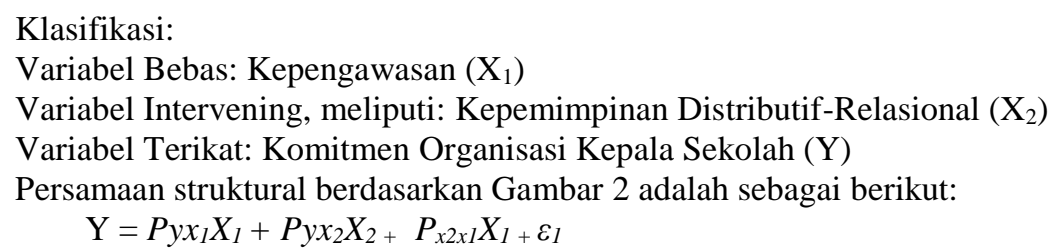

\section{HASIL PENELITIAN DAN PEMBAHASAN}

Hasil analisis deskriptif data hasil penelitian pada variabel kepengawasan menunjukkan nilai rerata (mean) pada masing-masing indikator variabel kepengawasan menghasilkan nilai indeks sebesar 59,3 yang berarti persepsi responden pada variabel kepengawasan termasuk dalam kategori sedang. Nilai rerata (mean) pada masing-masing indikator variabel kepemimpinan distributif-relasional menghasilkan nilai indeks sebesar 51,9 yang berarti persepsi responden pada variabel kepemimpinan distributif-relasional termasuk dalam kategori sedang. Nilai rerata (mean) pada masing-masing indikator variabel komitmen organisasi kepala sekolah menghasilkan nilai indeks sebesar 54,2 yang berarti persepsi responden pada variabel komitmen organisasi termasuk dalam kategori sedang.

Uji normalitas dalam penelitian ini dilakukan dengan program aplikasi SPSS 21 menggunakan kriteria One-Sample Kolmogorov-Smirnov Test diperoleh nilai signifikansiatau $p$ value 0,996 $(>0,05)$, yang berarti bahwa data berdistribusi normal. Uji Linieritas dalam penelitian ini menunjukkan bahwa variabel kepengawasan diperoleh nilai signifikansi 0,957 dan variabel kepemimpinan distributifrelasional diperoleh nilai signifikansi 0,111 lebih besar dari 0,05 , berarti terdapat hubungan linear secara 
Pengaruh Kepengawasan dan Kepemimpinan Distributif-Relasional Terhadap Komitmen Organisasi

Kepala Sekolah Dasar di Kabupaten Semarang (Sophia Tri Satyawati)

signifikan antara variabel. Nilai tolerance dan nilai VIF pada variabel Kepengawasan sebesar 0,783 1,277 dan Kepemimpinan Distributif - Relasional sebesar 0,494 - 2,024 menunjukkan nilai tolerance lebih besar dari 0,10 dan nilai VIF lebih kecil dari 10,00. Hal tersebut berarti tidak terjadi mulktikoloniaritas.

Hasil Analisis Regresi Dependen Variabel Adaptabilitas ditunjukkan pada Tabel 1 berikut.

Tabel 1. Hasil Analisis Persamaan Struktural Pengaruh Kepengawasan dan Kepemimpinan Distributif-Relasional terhadap Komitmen Organisasi

Coefficients $^{\mathbf{a}}$

\begin{tabular}{|c|c|c|c|c|c|c|c|c|}
\hline \multirow[b]{2}{*}{ Model } & \multicolumn{2}{|c|}{$\begin{array}{l}\text { Unstandardize } \\
\text { d Coefficients }\end{array}$} & \multirow{2}{*}{$\begin{array}{c}\text { Standardized } \\
\text { Coefficients } \\
\text { Beta }\end{array}$} & \multirow[b]{2}{*}{$\mathrm{t}$} & \multirow{2}{*}{ Sig. } & \multicolumn{3}{|c|}{$($ dalam \%) } \\
\hline & $\mathrm{B}$ & $\begin{array}{l}\text { Std. } \\
\text { Error }\end{array}$ & & & & $\begin{array}{l}\text { Direct } \\
\text { Effect }\end{array}$ & $\begin{array}{c}\text { Indirect } \\
\text { Effect }\end{array}$ & $\begin{array}{l}\text { Total } \\
\text { Effect }\end{array}$ \\
\hline Kepengawasan $\left(\mathrm{X}_{1}\right)$ & 0,256 & 0,053 & 0,343 & 4,848 & 0 & 11,76 & 13,25 & 25,01 \\
\hline Kepemimpinan D-R (X2) & 0,226 & 0,064 & 0,227 & 3,522 & 0,001 & 7,67 & - & 7,67 \\
\hline \multicolumn{9}{|c|}{ Dependent Variable: Komitmen Organisasi $\left(\mathrm{Y}_{2}\right)$} \\
\hline Adjusted R Square $\left(\mathrm{R}^{2}\right)=$ & & & & & & & & \\
\hline
\end{tabular}

Sumber: Data primer yang diolah, 2018

Besar koefisien jalur pengaruh variabel kepengawasan terhadap komitmen organisasi adalah sebesar 0,343 dengan arah positif dan pengaruhnya signifikan ditunjukkan dengan besarnya nilai uji t $=4,848$ lebih besar jika dibandingkan dengan $\mathrm{t}$ tabel alpha $0,05(\mathrm{df}=127)$ sebesar 1,656 . Hal berarti bahwa semakin baik atau semakin meningkat kepengawasan semakin meningkat pula komitmen organisasi. Besar pengaruh kepengawasan terhadap komitmen organisasi adalah sebesar 0,343 atau sebesar $(0,343)^{2}=0,1176$ atau $11,76 \%$. Dengan demikian dapat diketahui bahwa $11,76 \%$ perubahan yang terjadi pada komitmen organisasi secara langsung disebabkan adanya perubahan kepengawasan.

Besar koefisien jalur pengaruh variabel kepemimpinan distributif-relasional terhadap komitmen organisasi adalah sebesar 0,227 dengan arah positif dan pengaruhnya signifikan ditunjukkan dengan besarnya nilai uji $\mathrm{t}=3,522$ lebih besar jika dibandingkan dengan $\mathrm{t}$ tabel alpha $0,05(\mathrm{df}=127)$ sebesar 1,656. Hal berarti bahwa semakin baik atau semakin meningkat kepemimpinan distributifrelasional organisasi semakin meningkat pula komitmen organisasi. Besar pengaruh kepemimpinan distributif-relasional terhadap komitmen organisasi adalah sebesar 0,227 atau sebesar $(0,227)^{2}=0,0767$ atau 7,67\%. Dengan demikian dapat diketahui bahwa 7,67\% perubahan yang terjadi pada komitmen organisasi secara langsung disebabkan adanya perubahan kepemimpinan distributif-relasional..

Besar koefisien jalur pengaruh variabel kepemimpinan distributif-relasional terhadap komitmen organisasi adalah sebesar 0,227 dengan arah positif dan pengaruhnya signifikan ditunjukkan dengan besarnya nilai uji $\mathrm{t}=3,522$ lebih besar jika dibandingkan dengan $\mathrm{t}$ tabel alpha $0,05(\mathrm{df}=127)$ sebesar 1,656. Hal berarti bahwa semakin baik atau semakin meningkat kepemimpinan distributifrelasional organisasi semakin meningkat pula komitmen organisasi. Besar pengaruh kepemimpinan distributif-relasional terhadap komitmen organisasi adalah sebesar 0,227 atau sebesar $(0,227)^{2}=0,0767$ atau $7,67 \%$. Dengan demikian dapat diketahui bahwa 7,67\% perubahan yang terjadi pada komitmen organisasi secara langsung disebabkan adanya perubahan kepemimpinan distributif-relasional..

Pengaruh total terhadap variabel komitmen organisasi melalui kepemimpinan distributifrelasional adalah kepengawasan sebesar 25,01\%. Pengaruh tidak langsung terhadap variabel komitmen organisasi melalui kepemimpinan distributif-relasional adalah kepengawasan sebesar 13,25\%.

Besar koefisien simultan variabel kepengawasan dan kepemimpinan distributif-relasional terhadap komitmen organisasi sebesar 0,568 atau 56,8\% dan sisanya sebesar 43,2\% ditentukan oleh faktor lain di luar model.

Dari kedua variabel tersebut, pengaruh langsung yang lebih tinggi terhadap variabel komitmen organisasi adalah kepengawasan sebesar $11,76 \%$, dan pengaruh yang lebih kecil adalah kepemimpinan distributif-relasional sebesar 7,67\%.

Besar koefisien jalur pengaruh variabel kepengawasan terhadap komitmen organisasi dalam penelitian ini terbukti positif dan pengaruhnya signifikan, yang berarti bahwa semakin baik kepengawasan semakin baik pula komitmen organisasi. Hal tersebut mengindikasikan bahwa peningkatan kepengawasan akan meningkatkan komitmen organisasi. Dengan demikian hipotesis 
ketiga didukung. Besar pengaruh kepengawasan terhadap komitmen organisasi adalah sebesar 11,76\%, pengaruh tersebut merupakan pengaruh langsung yang signifikan dalam kategori sedang.

Sementara itu secara tidak langsung pengaruh kepengawasan terhadap komitmen organisasi karena hubungannya dengan kepemimpinan distributif-relasional adalah sebesar 13,25\% termasuk kategori sedang. Kemudian pengaruh total kepengawasan terhadap komitmen organisasi adalah sebesar $25,01 \%$, berarti kepengawasan mampu mempengaruhi secara langsung dan tidak langsung terhadap peningkatan komitmen organisasi dengan kategori sedang. Pengaruh kepengawasan terhadap komitmen organisasi akan semakin meningkat karena hubungannya dengan kepemimpinan distributif-relasional. Kepemimpinan distributif-relasional terbukti berdampak positif dalam meningkatkan pengaruh kepengawasan terhadap peningkatan komitmen organisasi Kepala Sekolah SD di Kabupaten Semarang.

Hasil empiris yang menunjukkan bahwa kepengawasan berpengaruh terhadap komitmen organisasi tersebut mengindikasikan bahwa pelaksanaan kepengawasan manajerial yang dilakukan oleh pengawas sekolah meliputi dimensi pembinaan, pemantauan, penilaian, pembimbingan dan pelatihan terbukti mampu meningkatkan komitmen organisasi, artinya semakin tinggi kepengawasan akan semakin meningkatkan komitmen organisasi. Demikian juga komitmen organisasi yang terdiri dari dimensi identifikasi, loyalitas, dan keterlibatan dapat ditingkatkan oleh kepengawasan manajerial pengawas sekolah.

Hasil penelitian ini sejalan dengan apa yang dikemukakan oleh Mowday, et al.(1979) dalam Sopiah (2008:164) mengemukakan bahwa pengawasan termasuk salah satu factor organisasi yang mempengaruhi komitmen yang dapat membentuk atau memunculkan tanggung jawab. Dalam penelitian ini kepengawasan diteliti melalui dimensi-dimensi pembinaan, pemantauan, penilaian, pembimbingan dan pelatihan memungkinkan pengawas sekolah untuk melakukan kepengawasan manajerial bagi kepala sekolah di sekolah binaannya secara efektif dapat meningkatkan komitmen organisasi kepala sekolah. Tanpa kepengawasan, dimungkinkan komitmen organisasi kepala sekolah akan stagnan/tidak berkembang, kepala sekolah kurang bisa bersikap setia, tanggung-jawab dan loyal.Kepala sekolah yang memiliki suatu komitmen, akan bekerja secara optimal sehingga dapat mencurahkan perhatian, pikiran, tenaga dan waktunya untuk pekerjaanya, sehingga apa yang sudah dikerjakannya sesuai dengan yang diharapkan oleh sekolah (Mowday, et al., 1979).

Untuk memastikan bahwa kepala sekolah memiliki komitmen organisasi yang tinggi peran kepengawasan dalam melaksanakan tugas pokok dan fungsinya di sekolah binaan sangat penting. Sebagaimana dalam Peraturan Menteri Pendidikan dan Kebudayaan Nomor 143 tahun 2014 tentang Petunjuk Teknis Pelaksanaan Jabatan Fungsional Pengawas Sekolah dan Angka Kreditnya, menyatakan bahwa pengawas sekolah adalah Pegawai Negeri Sipil (PNS) yang diberi tugas, tanggungjawab, dan wewenang secara penuh oleh pejabat yang berwenang untuk melaksanakan pengawasan akademik dan manajerial pada satuan pendidikan. Kepengawasan manajerial merupakan fungsi kepengawasan yang berkenaan dengan aspek pengelolaan sekolah yang terkait langsung dengan peningkatan pengembangan kompetensi sumber daya tenaga kependidikan/kepala sekolah (Sudjana dkk, 2011:21).

Hasil penelitian ini didukung oleh penelitian Febriani (2017) menunjukkan bahwa pengawasan berpengaruh positif dan signifikan terhadap komitmen organisasi. Penelitian Ratiningrum (2017) menunjukkan terdapat pengaruh yang signifikan secara parsial peran pengawas sekolah terhadap komitmen kepala sekolah SD di Kecamatan Seputih Banyak Kabupaten Lampung Tengah.

Besar koefisien jalur pengaruh variabel kepemimpinan distributif-relasional terhadap komitmen organisasi dalam penelitian ini terbukti positif dan pengaruhnya signifikan, yang berarti bahwa semakin baik kepemimpinan distributif-relasional semakin baik pula komitmen organisasi. Semakin tinggi tingat kepemimpinan distributif-relasional akan semakin meningkatkan komitmen organisasi. Dengan demikian hipotesis kelima didukung. Besar pengaruh kepemimpinan distributifrelasional terhadap komitmen organisasi adalah sebesar 7,67\%, dan pengaruh tersebut merupakan pengaruh langsung yang signifikan dalam kategori rendah..

Hasil empiris yang menunjukkan bahwa kepemimpinan distributif - relasional berpengaruh terhadap komitmen organisasi tersebut mengindikasikan bahwa pelaksanaan kepemimpinan distributif - relasional yang dilakukan oleh kepala sekolah meliputi dimensi support, supervision, collaboration, dan relasional terbukti mampu meningkatkan komitmen organisasi, artinya semakin tinggi kepemimpinan distributif - relasional akan semakin meningkatkan komitmen organisasi. Demikian juga komitmen organisasi yang terdiri dari dimensi identifikasi, loyalitas, dan keterlibatan dapat ditingkatkan oleh penerapan gaya kepemimpinan distributif - relasional. 
Penelitian ini sejalan dengan pendapat Sergiovanni (1987: 296), menyatakan bahwa kepemimpinan mengidentifikasi, menyusun dan mengarahkan sumber daya manusia membutuhkan tindakan komitmen untuk mencapai tujuan dan sasaran. Kuo, et al., (2009), mengemukakan bahwa pembentukan komitmen organisasi dapat dilakukan melalui gaya kepemimpinan, yaitu kemampuan pimpinan untuk memperhatikan sepenuhnya karyawan dengan pemberi motivasi dan komitmen organisasi melalui pemberian delegasi, tanggung jawab dan memberdayakan karyawan.

Hasil penelitian ini didukung oleh penelitian Hueryren Yeh, \& Dachuan Hong (2012), menunjukkan kepemimpinan positif dan signifikan mempengaruhi komitmen organisasi. Demikian juga hasil penelitian Indayati, Thoyib, \& Rofiaty (2012), Omidifar (2013) menunjukkan ada hubungan yang positif dan signifikan antara gaya kepemimpinan terhadap komitmen organisasi. Shalahuddin (2013), mengungkapkan bahwa kepemimpinan berpengaruh signifikan terhadap komitmen organisasional karyawan dengan arah hubungan yang positif. Hasil penelitian Nowack (2006) menemukan bahwa efektivitas kepemimpinan berpengaruh signifikan terhadap komitmen organisasional. Penelitian lain menemukan bahwa kepemimpinan terbukti memiliki dampak yang signifikan terhadap komitmen organisasional (Shirbagi, 2007). Hasil studi ini memperluas temuan hasil penelitian Cardona \& Lagomarsino (2003), menunjukkan bahwa kepemimpinan berpengaruh positif terhadap komitmen organisasional. Rabindarang, \& Bing (2012), menunjukkan bahwa kepemimpinan distributif adalah sesuai dengan pelaksanaan perubahan dalam organisasi sekolah, dan kepemimpinandistributif mempunyai hubungan signifikan dengan komitmen organisasi.

\section{SIMPULAN DAN SARAN}

Berdasarkan hasil penelitian dan pembahasan yang telah diuraian di atas, simpulan hasil penelitian ini adalah: (1) semakin baik kepengawasan akan semakin baik komitmen organisasi kepala sekolah, begitu pula sebaliknya apabila kepengawasan tidak baik mempunyai indikasi komitmen organisasi kepala sekolah juga tidak akan baik; (2) semakin baik kepemimpinan distributif-relasional akan semakin baik komitmen organisasi kepala sekolah, begitu pula sebaliknya apabila kepemimpinan distributif-relasional tidak baik mempunyai indikasi komitmen organisasi kepala sekolah juga tidak akan baik; (3) semakin baik kepengawasan akan semakin baik pula kepemimpinan distributif-relasional yang pada gilirannya akan semakin baik komitmen organisasi.

Beberapa saran yang dapat peneliti sampaikan berdasarkan hasil penelitian meliputi: (1) Peran pengawas sekolah sebagai pejabat fungsional dan tangan panjang Dinas Pendidikan, Kebudayaan, Pemuda, dan Olahraga (Disdikbudpora) Kabupaten Semarang dalam melaksanakan supervisi manajerial kepada kepala sekolah binaan diefektifkan dengan cara hasil pemantauan dan evaluasi yang telah dilaksanakan pengawas sekolah ditindaklanjuti dengan pembinaan dan pelatihan teknis terkait dengan peningkatan komitmen organisasi kepala sekoalah; (2) Kepala sekolah perlu mengimplementasikan kepemimpinan distributif-relasional secara optimal untuk mencapai visi, misi dan tujuan sekolah secara efektif dan efisien, karena hasil penelitian ini terbukti bahwa kepemimpinan distributif-relasional berpengaruh terhadap peningkatkan komitmen organisasi kepala sekolah baik secara langsung maupun tidak langsung; (3) kepala sekolah perlu meningkatkan komitmen organisasi dengan meningkatkan peran kepengawasan dan kepemimpinan distributif-relasional.

\section{DAFTAR PUSTAKA}

Amstrong, Michael. 1995. Personnel Management Practice. London: Kogan Cardona \& Lagomarsino.

Direktorat Jendral Pendidikan Menengah Kementerian Pendidikan dan Kebudayaan. 2013. Bahan Ajar: Pengembangan Karier Pengawas Sekolah Dikmen di Wilayah Timur melalui Pembinaan dan Pengembangan dan Benchmarking di wilayah Barat. Direktorat Pembinaan Pendidik dan tenaga Kependidikan Pendidikan Menengah

Duignan. 2004. "Forming capable leaders: from competence to capabilities". New Zealand Journal of Educational Leadership, 19(2): 5-13.

Elmore, Richard, F. 2000. Building a New Structure for School Leadership. The Albert Shanker Institute. www.ShankerInstitute.org. (diunduh tanggal 6 Agustus 2018). 
Febriani, D.S.H. \& Suharnomo.2017. "Pengaruh Pengawasan, Motivasi kerja, dan Komunikasi Interpersonal Terhadap Kinerja Karyawan Dengan Komitmen Organisasi Sebagai Variabel Intervenin (Studi Pada PT. Pos Indonesia (Persero) Cabang Ungaran). Undergraduate Thesis, Fakultas Ekonomika dan Bisnis UNDIP.

Hueryren Yeh \& Dachuan Hong. 2012.”'The Mediating Effect of Organizational Commitment on Leadership Type and Job Performance". The Journal of Human Resource and Adult Learning, $8(2): 50-59$

Hulpia, H, Devos, G \& Kerr, H, V . 2009. "The Relationship Between the Perception of Distributed Leadership in Secondary Schools and Teachers' and Teacher Leaders' J Job Satisfaction and Organizational Commitment". Journal School Effectiveness and School Improvement An International Journal of Research, Policy and Practice. 20(3).

Kuo. R.J., Wang, Y.C., Tien. F.C. 2009. "Integration of Artificial Neural Network and MADA Methods for Green Supplier Selection”. Journal of Cleaner Production. 18: 1161 - 1170.

Mangkunegara, A. P. 2006. Evaluasi Kinerja Sumber Daya Manusia. Jakarta: Refika Aditama.

Mowday, R., Steers, R \& Porter, L. 1979. “The Measurement of Organizational Commitment”. Journal of Vocational Behavior, 14: 224-247.

Nowack, K. (2006). "Optimising Employee Resilience: Coaching to Help Individuals Modify Lifestyle. Stress News". International Journal of Stress Management, 18: 9-12.

Omidifar, R. (2013). "Leadership Style, Organizational Commitment and Job Satisfaction: A Case Study on High School Principals in Tehran, Iran". American Journal of Humanities and Social Sciences, 1(4): 263-267.

Ouchi, William. (1981). Theory Z:How American Business Can Meet the Japanese Challenge. Reading. MA:Addison-Wesley.

Pratiwi Saraswati, 2007. "Pengaruh kepuasan Komunikasi Terhadap Komitmen Organisasi Pada Karyawan Rumah Sakit Bunda Surabaya". Thesis, Universitas Airlangga.

Rabindarang, S \& Bing K,W., 2014. "The Influence of Distributed Leadership on Job Stress in Technical and Vocational Education". International Journal of Academic Research in Business and Social Sciences, 4(1):490-499.

Ratriningrum, F. 2017. Pengaruh Pengawas Sekolah, Kepala Sekolah, dan Komitmen Kerja Terhadap Kompetensi Pedagogik Guru Sekolah Dasar di Kecamatan Seputih Banyak Kabupaten Lampung Tengah, Tesis, FKIP Universitas Lampung, Bandar lampung.

Robbins, S.P, \& Judge, T.A. 2015. Perilaku Organisasi (Organizational Behavior). Jakarta: Salemba Empat Rosnarizah.

Salancik, G.R. 1995. Commitment and the Control of Organizational Behaviorand Belief, Psychological Dimensions of Organizational Behavior, ed. Barry M Staw . New Jersey: Prentice-Hall Sergiovanny.

Simanjuntak, P. J. 2011. Manajemen \& Evaluasi Kinerja. Jakarta:Fakultas.

Sopiah. 2008. Perilaku Organisasional. Yogyakarta : C.V Andi OffseSopiah.

Shalahuddin, A. 2013. Pengaruh Kepemimpinan dan Lingkungan Kerja Terhadap Komitmen Organisasional dan Kinerja Karyawan PT. Sumber Djantin Di Kalimantan Barat. Jurnal Manajemen Teori dan Terapan. 6(2):89-104.

Shirbagi, Naser. 2007. "Exploring Organizational Commitmen and Lidership Frames within Indian and Iriani Higher Education Institutions". Bulletin of Education \& Research. 29(1): 17-32.

Sudjana, N., et al. 2011. Supervisi Pendidikan Konsep dan Aplikasinya Bagi Pengawas Sekolah. Cikarang Bekasi:Binamitra Publishing. 